\title{
Methodological approaches for the selection of genotypes in a progeny trial of Dacryodes edulis (G. Don) H. J. Lam in Cameroon
}

\author{
Tchapda Dorothy TCHATCHOUA ${ }^{1,2^{*}}$, Zac TCHOUNDJEU $^{1}$, Ebenezar ASAAH $^{1}$, \\ Alain TSOBENG ${ }^{1}$, John C. WEBER ${ }^{3}$ and Antoine KALINGANIRE ${ }^{3}$ \\ ${ }^{1}$ World Agroforestry Centre, (ICRAF), B.P. 16317, Yaoundé, Cameroon. \\ ${ }^{2}$ Department of Agriculture, Animal Husbandry and Derived Products. Higher Institute of the Sahel (ISS), \\ University of Maroua. P.O. Box 46 Maroua- Cameroon. \\ ${ }^{3}$ World Agroforestry Centre, (ICRAF), B.P. E-5118, Bamako, Mali. \\ "Correspondence author, E-mail: tchatchouad@yahoo.com, Tel: (237) 77598313
}

\begin{abstract}
The World Agroforestry Centre (ICRAF) initiated a program in Cameroon for the selection of improved genotypes of Dacryodes edulis for domestication. There are major challenges in such selection because superior performance of individual trees may be based on site conditions rather than on genetic differences. Open-pollinated seeds were collected from mother trees in four provenances in Cameroon and planted in a progeny trial at Minkoameyos, Cameroon. Progeny from the same mother tree are referred to as family. After one year of growth in the field, growth traits were measured annually for five years and fruit traits were measured in two successive years. Three methodological approaches were investigated: family and within-family selection (combined selection), ranking for phenotypic selection and correlation for multi-trait and early selection. Variation in growth and fruit traits among families was not significant for most provenances, indicating that family selection would not be effective for the selection of genotypes in the trial. Phenotypic selection resulted in the retention of a small number of individuals of all families in the trial. There were strong positive correlations between fruit traits and between fruit and growth traits, while negative correlations were found between fruit traits and yield. The correlations indicate that selecting for one fruit trait may also improve the other fruit traits but reduce fruit yield. Positive and significant juvenile-mature correlations for growth were also found in this trial, indicating that early selection may be possible based on growth. Based on these results, phenotypic selection is recommended in the progeny trial for the domestication program in Cameroon and further research on early selection is needed as the trial advances in age.
\end{abstract}

(C) 2012 International Formulae Group. All rights reserved.

Keywords: Domestication, tree growth, fruit traits, family variation, correlations, early selection

\section{INTRODUCTION}

The World Agroforestry Centre (ICRAF), in collaboration with national agricultural research institute in West and Central Africa Regions have been domesticating the high-value indigenous fruit and medicinal trees for the last decade (Tchoundjeu et al., 2006). Five species were selected based on farmers' preferences and the market potential of the species. Dacryodes edulis (G. Don) H. J. Lam (Burseraceae family) was ranked second amongst species 
that farmers selected for the domestication program after Irvingia gabonensis (Aubrey Lecomte ex O'Rorke) Baillon (Franzel et al., 1996). D. edulis is known as African plum or safou in Cameroon and bush butter in Nigeria. It is a dioecious, small to medium-sized tree up to 20-25 $\mathrm{m}$ tall. It is an important fruit tree at the national and international levels, because the fruit has high nutritional value and plays an important role in the rural economy (Awono et al., 2002; Mbofung et al., 2002; Schreckenberg et al., 2002a). The species originated from Central Africa and the Gulf of Guinea and is presently cultivated from Sierra Leone to Angola along the Atlantic coast and further inland as far as Uganda (Leakey et al., 2002). It has also been recorded in northern Zimbabwe.

A progeny test of safou was established in Minkoameyos in 2001 from four provenances. The trial was planted for the selection of superior genotypes to be used in the on-going domestication program. There are major challenges in such selection as superior performance of individual trees may be based more on environmental than on genetic differences. Furthermore, reliance on only a few trees as a basis for future expansion will narrow the genetic base and make the material vulnerable to changing disease pressures and/or climate change (Cornelius et al., 2006). In any selection the expected gain in performance must thus be weighed against the risk of future costs due to higher vulnerability.

A number of selection methods are available for improving gain. Combined index selection is employed based on the breeding values, whereas phenotypic selection ranks the individual based on its phenotypic value without any knowledge about the genetic parameters (Falconer and Mackay, 1996). Shelbourne (1992) found that phenotypic selection in unpedigreed stands, resulted in lower genetic gain than elaborate strategies, but was favorable when possibilities for faster generation turn-over and lower cost were taken into account. Furthermore, as demonstrated experimentally, if the selection intensity is relatively low (e.g., $20 \%$ selected) then phenotypic selection based on tree growth traits can produce genetic gain without significantly reducing genetic variation in the growth traits in the next generation (Weber et al., 2009). Genetic improvement of several traits simultaneously is often needed in a breeding program and this requires that information about several traits be included in the selection procedure. Trait-trait correlations have been estimated for many trees and used for developing a domestication strategy (e.g., White et al., 2007; Sotelo et al., 2010).

Domestication of most trees species is a slow process due to their long life span. Developing techniques to select at an early age would speed up the process, but this requires that the traits are at least moderately heritable at an early age and juvenile-mature correlations are strong and positive.

This paper presents methodological approaches for the selection of genotypes in the progeny trial of safou based on tree growth and fruit traits. The specific objectives are to (a) determine if there is significant genetic variation within provenances for family and within-family selection, (b) use a ranking procedure to phenotypically select progeny based on their growth and fruit traits, and (c) determine if the correlations between traits at the same age and if the correlations for the same trait at different ages are sufficiently strong to allow multiple-trait selection at an early age.

\section{MATERIALS AND METHODS Selection of candidate plus-trees}

Field visits to identify candidate plustrees in terms of desired fruit traits were conducted by ICRAF technical staff and farmers in 2001 (Tchoundjeu et al., 2002). In Cameroon, D. edulis is cultivated and marketed in the humid lowland zone (Isseri, 1998). Four populations (Boumeyebel, Makenene, Kekem and Ongot, hereafter referred to as provenances) were identified for collection and represent the two agroecological zones in Cameroon (i.e. with one or two annual rainy seasons). These zones are 
located between latitude $2^{\circ} 6^{\prime}-6^{\circ} 12^{\prime} \mathrm{N}$ and longitude $8^{\circ} 48^{\prime}-16^{\circ} 12^{\prime}$ E. Altitudes ranged from 500-2000 m, mean annual rainfall ranged from 1500-2500 $\mathrm{mm}$ and soil $\mathrm{pH}$ was 4-4.8. The maximum distance between provenances was $200 \mathrm{~km}$. Five candidate plus trees were selected in each provenance, with at least $100 \mathrm{~m}$ between each selected tree in each provenance. The trees were selected based on fruit size and flavor, mesocarp colour, fruiting season, frequency of fruiting and resistance to pests and diseases. The selected trees were located in household gardens, farmlands and secondary forests. Information on the geographical location was recorded for each selected tree.

Fifty seeds were randomly sampled from each tree, sown and grown in polythene bags at ICRAF's research nursery in Yaoundé, Cameroon. Seedlings were transplanted in the progeny trial after six months growth in the nursery. The progeny trial includes four provenances, five families per provenance and 30 progeny plants per family, and was established in Minkoameyos, located near Yaoundé. Minkoameyos is in the humid lowland zone, with two rainy seasons per year. Each provenance was established at a different site, but the maximum distance between the four sites was only about $100 \mathrm{~m}$, so the sites had similar environmental conditions (latitude $=3^{\circ} 51-58^{\prime} \mathrm{N}$, longitude $=$ $11^{\circ} 25-27^{\prime} \mathrm{E}$, altitude $=813 \mathrm{~m}$, mean annual rainfall $=1295 \mathrm{~mm}$, soil $\mathrm{pH}=4-5.5)$. Each site included 15 replications, and in each replication there were two-tree row plots for each of the five families (30 seedlings total per family). Seedlings were planted in manure-filled holes at a spacing of 5 by $5 \mathrm{~m}$. Border trees of safou from unknown provenances were planted around each site at the same spacing.

\section{Data collection}

After one year of growth in the field, growth parameters were measured annually for five years and fruit traits were assessed at the onset of fruiting following a standard procedure (Leakey et al., 2002; Waruhiu et al.,
2004). Growth traits included height ( $\mathrm{Ht})$, root collar diameter (CD) and crown diameter (CR) of all living trees at the end of the growing season. The number of fruits was recorded in each fruiting season for trees with fruits, and 30 fruits were randomly selected from the four cardinal quadrants of the canopy for measurement of fruit variables. These included fruit length, width and pulp thickness (mm); total fruit weight, kernel weight and pulp weight (gm); and pulp weight as a percentage of total fruit weight.

\section{Data analysis}

Variables studied included survival, growth traits, fruit traits and fruit yield (i.e. the number of fruits produced). Due to fire damage and the low percentage of trees with fruit, many trees were not included in the analyses. Because the provenances were not replicated on the same site, data were analyzed separately by provenance (site).

Using the SPSS statistical package, one way analysis of variance (ANOVA) was used to determine if there were significant differences among families within provenances. The ANOVA model was $\mathrm{Y}_{\mathrm{ij}}=\mu$ $+F_{i}+\varepsilon_{j}$ where, $\mu=$ overall mean, $F_{i}=$ effect of family and $\varepsilon_{\mathrm{j}}=$ the experimental error.

The Krustal Wallis test was used to rank the genotypes based upon their phenotypic values and determine if ranked values were significantly different. The top $20 \%$ of genotypes for each trait were then selected.

Spearman non-parametric correlation coefficients were used to determine if there were significant relationships between different traits at the same age and between the same trait at different ages.

\section{RESULTS \\ Survival}

Survival rate in the provenances was $73 \%, 81 \%, 89 \%$ and $92 \%$ for Ongot, Boumyebel, Makenene and Kekem, respectively after six years. Mortality was caused by accidental fire and loss during weeding at the first year of growth. 


\section{Variation in tree growth and fruit traits}

Mean tree height was $4.8 \mathrm{~m}$ in each provenance after six years. The values for height, root collar diameter and crown diameter of individual trees ranged from 1.8 to $8.1 \mathrm{~m}, 1.3$ to $16.2 \mathrm{~cm}$ and 0.43 to $18.0 \mathrm{~m}$, respectively across the four provenances in the sixth year. Except for all the families in Ongot provenance and a few families in Boumyebel provenance, ANOVA indicated that the differences among families within provenances were not significant (Table 1). There were significant differences in most fruit traits among families of the Boumyebel and Kekem provenances in the sixth year (Table 2). However, most fruit traits did not differ significantly among families in the Makenene and Ongot provenances.

\section{Ranking genotypes based on tree growth traits}

In this trial, the best $20 \%$ of the genotypes based on the three growth traits (tree height, root collar and crown diameters) represented all families from the four provenances. The number of selected genotypes was 27 from Kekem, 25 from Ongot, 22 from Makenene and 16 from Boumyebel. Since all 20 families from the four provenances are represented in the selected group, there is a relatively broad genetic base for the improvement program. Since the growth traits were highly correlated (discussed below and details in Table 3), the majority of the selected genotypes in each provenance were in the top $20 \%$ for at least two of the three growth traits: 23 from Kekem, 18 from Ongot and from Makenene, and 13 from Boumyebel.

\section{Ranking of genotypes based on fruit traits and yields}

Among genotypes selected based on fruit traits, eight genotypes from Boumyebel, one from Makenene, two from Kekem and three from Ongot provenance were in the top $20 \%$ for all five fruit traits. In addition, most of the genotypes were in the top $20 \%$ for three or four of the five fruit traits. This reflects the positive correlations among the fruit traits (Table 4), and indicates that selection of genotypes with multiple-trait superiority is possible. Concerning yields, very few genotypes were in the top $20 \%$ for both fruit traits and yield because of the negative correlation between the fruit traits and yield.

\section{Correlations among tree growth and fruit traits}

There were strong, positive and significant correlations among growth traits in years two through six (Table 3), Correlations indicated that trees with larger root collar diameter had significantly larger crown diameter in all the provenances. Correlations were low between height and root collar diameter and between height and crown diameter for the Makenene provenance. There was no obvious trend between the magnitude of the correlation and the age of the trees.

Correlations among fruit traits (fruit length, fruit width, pulp thickness, fruit weight, pulp weight and percentage pulp) were strong and positive in most of the provenances in the sixth year (Table 4). The strongest correlation was between pulp weight and fruit weight in all the provenances. Correlations between fruit traits and yields (number of fruits) were weak, but negative in all the provenances.

Some fruit traits were significantly correlated with growth traits (Table 5): negative correlations with height (except in Ongot provenance), and; - positive correlations with tree collar diameter (except in Kekem provenance) and crown diameter in all the provenances. Furthermore, correlations between yield and growth traits were positive in most provenances.

\section{Juvenile-mature correlations}

In general, there were significant, positive correlations between growth traits at different ages (Table 6) and the correlations were generally stronger between two consecutive years (e.g. year 2 and 3 ) and weakest between the first and the last measurement year. 
Fruit production started in the fifth year and increased notably in the sixth year. The percentage of trees with fruits was $12 \%$ for Boumyebel, $15 \%$ for Kekem, $18 \%$ for Makenene, and 9\% for Ongot in year 5; and $46 \%$ for Boumyebel, $48 \%$ for Kekem, 38\% for Makenene and 22\% for Ongot in year 6 . Correlations among fruit traits were positive but not significant between the two years (not tabled). Trees had many flowers during the flowering season but only a few fruits at the end of the fruiting season: strong winds and early rains during flowering and onset of fruit probably knocked off the flowers and young fruits.

Table 1: Mean and significance of family variation for tree growth traits in four provenances of Dacryodes edulis in years two through six.

\begin{tabular}{|c|c|c|c|c|c|}
\hline Provenance/year & 2 & 3 & 4 & 5 & 6 \\
\hline \multicolumn{6}{|c|}{ Mean } \\
\hline \multicolumn{6}{|l|}{ Tree height (m) } \\
\hline Boumyebel & 1.2 & 1.7 & 2.7 & 3.7 & 4.7 \\
\hline Kekem & 1.2 & 1.7 & 2.6 & 3.7 & 4.8 \\
\hline Makenene & 1.3 & 1.8 & 3.9 & 4.8 & 4.8 \\
\hline Ongot & 1.2 & 1.6 & 2.6 & $3.6^{* *}$ & $4.8^{* * *}$ \\
\hline \multicolumn{6}{|c|}{ Root collar diameter $(\mathbf{c m})$} \\
\hline Boumyebel & 2.5 & 3.8 & 6.3 & 9.0 & 10.6 \\
\hline Kekem & 3.9 & 3.8 & 6.8 & - & 11.0 \\
\hline Makenene & 2.8 & 4.0 & 6.9 & 9.4 & 10.6 \\
\hline Ongot & 2.5 & 3.6 & $5.9 * *$ & $8.5^{*}$ & $10.2 * * *$ \\
\hline \multicolumn{6}{|c|}{ Crown diameter (m) } \\
\hline Boumyebel & 87 & 1.14 & 1.56 & 2.36 & 3.63 \\
\hline Kekem & 1.0 & 1.1 & 1.6 & 2.6 & 4.0 \\
\hline Makenene & 0.93 & 1.12 & 1.6 & 2.3 & 3.7 \\
\hline Ongot & $0.8 * * *$ & $1.1 * *$ & $1.5 * * *$ & 2.1 & $3.5 * * *$ \\
\hline
\end{tabular}

Table 2: Mean and significance of family variation for fruit traits in year six in four provenances of Dacryodes edulis

\begin{tabular}{|c|c|c|c|c|c|c|c|c|}
\hline Trait/Provenance & FL & FW & PT & FWGT & KWGT & PWGT & $\mathbf{P \%}$ & NF \\
\hline \multicolumn{9}{|c|}{ Mean } \\
\hline Boumyebel & $82.8 * * *$ & $40.2 * *$ & $6.6 * * *$ & $65.9 * * *$ & $12.7 *$ & $53.2 * * *$ & $78.5 * *$ & 248.6 \\
\hline Kekem & $71.7 * *$ & $36.9 * * *$ & $6.3 * *$ & $50.3 *$ & 11.6 & $38.7 *$ & 75.7 & 238.2 \\
\hline Makenene & $73.8 *$ & 38.4 & 6.7 & 54.5 & 12.2 & 42.3 & 76.6 & 197.2 \\
\hline Ongot & 70.8 & 35.0 & $5.1 * *$ & 43.9 & 12.2 & 31.8 & $71.1 * *$ & 295.3 \\
\hline
\end{tabular}


Table 3: Correlations among tree growth traits in four provenances of Dacryodes edulis in year two to six.

\begin{tabular}{|c|c|c|c|c|c|c|c|}
\hline \multicolumn{4}{|c|}{ Boumyebel } & \multicolumn{4}{|c|}{ Ongot } \\
\hline & $\mathrm{Ht} 2$ & CD2 & CR2 & & Ht2 & $\mathrm{CD} 2$ & CR2 \\
\hline $\mathrm{Ht} 2$ & 1 & & & $\mathrm{Ht} 2$ & 1 & & \\
\hline $\mathrm{CD} 2$ & $0.860^{* * *}$ & 1 & & CD2 & $0.792 * *$ & 1 & \\
\hline \multirow[t]{2}{*}{ CR2 } & $0.869 * *$ & $0.835^{* *}$ & 1 & CR2 & $0.806^{* *}$ & $0.776^{* *}$ & 1 \\
\hline & $\mathrm{Ht} 3$ & $\mathrm{CD} 3$ & CR3 & & $\mathrm{Ht} 3$ & $\mathrm{CD} 3$ & CR3 \\
\hline $\mathrm{Ht} 3$ & 1 & & & $\mathrm{Ht} 3$ & 1 & & \\
\hline CD3 & $0.899 * *$ & 1 & & CD3 & $0.849 * *$ & 1 & \\
\hline \multirow[t]{2}{*}{ CR3 } & $0.822 * *$ & $0.877^{* *}$ & 1 & CR3 & $0.784 * *$ & $0.820^{* *}$ & 1 \\
\hline & $\mathrm{Ht} 4$ & CD4 & CR4 & & $\mathrm{Ht} 4$ & CD4 & CR4 \\
\hline $\mathrm{Ht} 4$ & 1 & & & $\mathrm{Ht} 4$ & 1 & & \\
\hline CD4 & $0.871^{* * *}$ & 1 & & CD4 & $0.748 * *$ & 1 & \\
\hline \multirow[t]{2}{*}{ CR4 } & $0.633 * *$ & $0.759 * *$ & 1 & CR4 & $0.597 * *$ & $0.829 * *$ & 1 \\
\hline & $\mathrm{Ht} 5$ & CD5 & CR5 & & $\mathrm{Ht} 5$ & CD5 & CR5 \\
\hline $\mathrm{Ht} 5$ & 1 & & & $\mathrm{Ht} 5$ & 1 & & \\
\hline CD5 & $0.834 * *$ & 1 & & CD5 & $0.844 * *$ & 1 & \\
\hline \multirow[t]{2}{*}{ CR5 } & $0.663 * *$ & $0.827 * *$ & 1 & CR5 & $0.653 * *$ & $0.782 * *$ & 1 \\
\hline & $\mathrm{Ht} 6$ & CD6 & CR6 & & $\mathrm{Ht} 6$ & CD6 & CR6 \\
\hline $\mathrm{Ht} 6$ & 1 & & & $\mathrm{Ht} 6$ & 1 & & \\
\hline CD6 & NS & 1 & & CD6 & $0.825 * *$ & 1 & \\
\hline CR6 & NS & $0.712 * *$ & 1 & CR6 & $0.647 * *$ & $0.821 * *$ & 1 \\
\hline
\end{tabular}

(Table 3 con't)

\begin{tabular}{|c|c|c|c|c|c|c|c|}
\hline \multicolumn{4}{|c|}{ Makenene } & \multicolumn{4}{|c|}{ Kekem } \\
\hline & $\mathrm{Ht} 2$ & CD2 & CR2 & & $\mathrm{Ht} 2$ & CD2 & $\overline{\mathrm{CR} 2}$ \\
\hline $\mathrm{Ht} 2$ & 1 & & & $\mathrm{Ht} 2$ & 1 & & \\
\hline $\mathrm{CD} 2$ & $0.234 *$ & 1 & & $\mathrm{CD} 2$ & $0.799 * *$ & 1 & \\
\hline \multirow[t]{2}{*}{ CR2 } & NS & $0.754 * *$ & 1 & CR2 & $0.689 * *$ & $0.758 * *$ & 1 \\
\hline & $\mathrm{Ht} 3$ & CD3 & CR3 & & $\mathrm{Ht} 3$ & CD3 & CR3 \\
\hline $\mathrm{Ht} 3$ & 1 & & & $\mathrm{Ht} 3$ & 1 & & \\
\hline CD3 & NS & 1 & & $\mathrm{CD} 3$ & $0.869 * *$ & 1 & \\
\hline \multirow[t]{2}{*}{ CR3 } & NS & $0.668 * *$ & 1 & CR3 & $0.741^{* *}$ & $0.770 * *$ & 1 \\
\hline & $\mathrm{Ht} 4$ & CD4 & CR4 & & $\mathrm{Ht} 4$ & CD4 & CR4 \\
\hline $\mathrm{Ht} 4$ & 1 & & & $\mathrm{Ht} 4$ & 1 & & \\
\hline CD4 & NS & 1 & & CD4 & $0.833^{* *}$ & 1 & \\
\hline \multirow[t]{2}{*}{ CR4 } & NS & $0.588 * *$ & 1 & CR4 & $0.700 * *$ & $0.776^{* *}$ & 1 \\
\hline & $\mathrm{Ht} 5$ & CD5 & CR5 & & Ht 6 & CD6 & CR6 \\
\hline $\mathrm{Ht} 5$ & 1 & & & Ht6 & 1 & & \\
\hline CD5 & NS & 1 & & CD6 & $0.584 * *$ & 1 & \\
\hline \multirow[t]{2}{*}{ CR5 } & NS & $0.713^{* *}$ & 1 & CR6 & $0.444^{* *}$ & $0.836^{* *}$ & 1 \\
\hline & Ht6 & CD6 & CR6 & & & & \\
\hline Ht6 & 1 & & & & & & \\
\hline CD6 & NS & 1 & & & & & \\
\hline CR6 & NS & $0.737 * *$ & 1 & & & & \\
\hline
\end{tabular}


Table 4: Correlations among fruit traits in four provenances of Dacryodes edulis in year six.

\begin{tabular}{|c|c|c|c|c|c|c|c|c|}
\hline & FL & FW & PT & FWGT & KWGT & PWGT & P \% & NF \\
\hline \multicolumn{9}{|c|}{ Boumeyebel } \\
\hline FL & 1 & & & & & & & \\
\hline FW & $0.720 * *$ & 1 & & & & & & \\
\hline PT & $0.760 * *$ & $0.786^{* *}$ & 1 & & & & & \\
\hline FWGT & $0.852 * *$ & $0.924 * *$ & $0.877 * *$ & 1 & & & & \\
\hline KWGT & $0.322 * *$ & $0.337 * *$ & NS & $0.330^{* *}$ & 1 & & & \\
\hline PWGT & $0.840 * *$ & $0.913 * *$ & $0.884 * *$ & $0.992 * *$ & NS & 1 & & \\
\hline P \% & $0.769 * *$ & $0.785^{* *}$ & $0.828 * *$ & $0.815^{* *}$ & NS & $0.862 * *$ & 1 & \\
\hline NF. & NS & $-0.307^{*}$ & NS & NS & NS & $-0.262 *$ & $-0.374 * *$ & 1 \\
\hline \multicolumn{9}{|l|}{ Kekem } \\
\hline FL & 1 & & & & & & & \\
\hline FW & $0.308^{* *}$ & 1 & & & & & & \\
\hline PT & $0.433 * *$ & $0.840^{* *}$ & 1 & & & & & \\
\hline FWGT & $0.660 * *$ & $0.867 * *$ & $0.888 * *$ & 1 & & & & \\
\hline KWGT & $0.454 * *$ & $0.351 * *$ & $0.436^{* *}$ & $0.597 * *$ & 1 & & & \\
\hline PWGT & $0.639 * *$ & $0.890^{* *}$ & $0.895^{* *}$ & $0.986^{* *}$ & $0.456^{* *}$ & 1 & & \\
\hline $\mathrm{P} \%$ & $0.474 * *$ & $0.699 * *$ & $0.676^{* *}$ & $0.656^{* *}$ & NS & $0.756^{* *}$ & 1 & \\
\hline NF. & NS & NS & NS & NS & NS & NS & NS & 1 \\
\hline \multicolumn{9}{|c|}{ Makenene } \\
\hline FL & 1 & & & & & & & \\
\hline FW & $0.341 * *$ & 1 & & & & & & \\
\hline PT & $0.486^{* *}$ & $0.761 * *$ & 1 & & & & & \\
\hline FWGT & $0.747 * *$ & $0.760 * *$ & $0.839 * *$ & 1 & & & & \\
\hline KWGT & NS & NS & NS & $0.264^{*}$ & 1 & & & \\
\hline PWGT & $0.737 * *$ & $0.798^{* *}$ & $0.855^{* *}$ & $0.975^{* *}$ & NS & 1 & & \\
\hline $\mathrm{P} \%$ & $0.468 * *$ & $0.657 * *$ & $0.616^{* *}$ & $0.551^{* *}$ & $-0.601 * *$ & $0.707 * *$ & 1 & \\
\hline NF. & NS & NS & NS & NS & $0.352 * *$ & NS & NS & 1 \\
\hline \multicolumn{9}{|l|}{ Ongot } \\
\hline FL & 1 & & & & & & & \\
\hline FW & $0.640 * *$ & 1 & & & & & & \\
\hline PT & $0.624 * *$ & $0.793^{* *}$ & 1 & & & & & \\
\hline FWGT & $0.678^{* *}$ & $0.846^{* *}$ & $0.702 * *$ & 1 & & & & \\
\hline KWGT & $0.570 * *$ & $0.551^{* *}$ & $0.462 * *$ & $0.764^{* *}$ & 1 & & & \\
\hline PWGT & $0.652 * *$ & $0.859 * *$ & $0.711 * *$ & $0.983^{* *}$ & $0.633 * *$ & 1 & & \\
\hline $\mathrm{P} \%$ & $0.373^{*}$ & $0.648^{* *}$ & $0.612 * *$ & $0.612 * *$ & NS & $0.733 * *$ & 1 & \\
\hline NF. & NS & NS & NS & NS & NS & NS & NS & 1 \\
\hline
\end{tabular}

Variables: $\mathrm{FL}=$ fruit length, FW $=$ fruit width, $\mathrm{PT}=$ pulp thickness, $\mathrm{FWGT}=$ fruit weight, $\mathrm{KWGT}=$ kernel weight, $\mathrm{PWGT}=$ pulp weight $\mathrm{P} \%=$ pulp percentage, $\mathrm{NF}=$ number of fruits.

Significance: $* \mathrm{P}<0.05$, ** $\mathrm{P}<0.01$, NS $\mathrm{P}>0.05$.

Sample size: 50-67 for Boumyebel, 66-73 for Kekem, 48-56 for Makenene, 27-30 for Ongot. 
Table 5: Correlations between tree growth and fruit traits in four provenances of Dacryodes edulis in year six.

\begin{tabular}{|c|c|c|c|c|c|c|c|c|}
\hline & FL & FW & PT & FWGT & KWGT & PWGT & P \% & NF. \\
\hline \multicolumn{9}{|c|}{ Boumeyebel } \\
\hline $\mathrm{Ht}$ & NS & NS & NS & NS & NS & NS & NS & NS \\
\hline $\mathrm{CD}$ & $0.308 *$ & $0.280 *$ & $0.330 * *$ & $0.339 * *$ & NS & $0.330^{* *}$ & $0.285^{*}$ & $0.252 *$ \\
\hline $\mathrm{CR}$ & NS & NS & NS & NS & NS & NS & NS & NS \\
\hline \multicolumn{9}{|c|}{ Kekem } \\
\hline $\mathrm{Ht}$ & NS & NS & NS & NS & NS & NS & NS & NS \\
\hline $\mathrm{CD}$ & NS & NS & NS & NS & NS & NS & NS & NS \\
\hline $\mathrm{CR}$ & NS & NS & NS & NS & NS & NS & NS & NS \\
\hline \multicolumn{9}{|c|}{ Makenene } \\
\hline $\mathrm{Ht}$ & NS & $-0.289^{*}$ & NS & NS & NS & NS & NS & NS \\
\hline $\mathrm{CD}$ & $0.284 *$ & NS & NS & $0.333^{*}$ & NS & $0.292 *$ & NS & $0.442 * *$ \\
\hline $\mathrm{CR}$ & NS & NS & NS & NS & NS & NS & NS & $0.392 * *$ \\
\hline \multicolumn{9}{|c|}{ Ongot } \\
\hline $\mathrm{Ht}$ & $0.422 *$ & NS & $0.354^{*}$ & $0.358^{*}$ & NS & $0.385^{*}$ & NS & NS \\
\hline $\mathrm{CD}$ & $0.535^{* *}$ & NS & NS & NS & $0.415^{*}$ & NS & NS & $0.477 * *$ \\
\hline $\mathrm{CR}$ & $0.343^{*}$ & NS & NS & NS & NS & NS & $-\mathrm{NS}$ & NS \\
\hline
\end{tabular}

Table 6: Juvenile-mature correlations for tree growth traits in four provenances of Dacryodes edulis in year two to six.

\section{A. Tree height}

\begin{tabular}{llllll}
\hline Year & $\mathbf{2}$ & $\mathbf{3}$ & $\mathbf{4}$ & $\mathbf{5}$ & $\mathbf{6}$ \\
\hline Boumyebel & 1 & & & & \\
2 & $0.956^{* *}$ & 1 & & & \\
3 & $0.873^{* *}$ & $0.904^{* *}$ & 1 & & \\
4 & $0.617^{* *}$ & $0.588^{* *}$ & $0.642^{* *}$ & 1 & \\
5 & $-0.235^{*}$ & $\mathrm{NS}$ & $\mathrm{NS}$ & $-0.236^{*}$ & 1 \\
6 & & & & & \\
Kekem & 1 & & & & \\
2 & $0.818^{* *}$ & 1 & & & \\
3 & $0.457^{* *}$ & $0.611^{* *}$ & 1 & & \\
4 & $0.302^{* *}$ & $0.420^{* *}$ & $0.506^{* *}$ & 1 & \\
5 & $0.304^{* *}$ & $0.437^{* *}$ & $0.368^{* *}$ & $\mathrm{NS}$ & 1 \\
6 & & & & & \\
Makenene & 1 & & & & \\
2 & $0.933^{* *}$ & 1 & & & \\
3 & & & & &
\end{tabular}




\begin{tabular}{llllll}
4 & $0.828 * *$ & $0.898 * *$ & 1 & & \\
5 & $0.360 * *$ & $0.418 * *$ & $0.560 * *$ & 1 & \\
6 & NS & $0.230 *$ & $0.269 * *$ & NS & 1 \\
Ongot & & & & & \\
2 & 1 & & & & \\
3 & $0.860 * *$ & 1 & & & \\
4 & $0.718 * *$ & $0.760 * *$ & 1 & & \\
5 & $0.358 * *$ & $0.402 * *$ & $0.622 * *$ & 1 & \\
6 & $0.532 * *$ & $0.492 * *$ & $0.540 * *$ & $0.464 * *$ & 1 \\
\hline
\end{tabular}

\section{B. Root collar diameter}

\begin{tabular}{|c|c|c|c|c|c|}
\hline Year & 2 & 3 & 4 & 5 & 6 \\
\hline \multicolumn{6}{|c|}{ Boumyebel } \\
\hline 2 & 1 & & & & \\
\hline 3 & $0.891 * *$ & 1 & & & \\
\hline 4 & $0.816^{* *}$ & $0.945^{* *}$ & 1 & & \\
\hline 5 & $0.623^{* *}$ & $0.646^{* *}$ & $0.650^{* *}$ & 1 & \\
\hline 6 & $0.709 * *$ & $0.740^{* *}$ & $0.843^{* *}$ & $0.640^{* *}$ & 1 \\
\hline \multicolumn{6}{|c|}{ Kekem } \\
\hline 2 & 1 & & & & \\
\hline 3 & $0.834 * *$ & 1 & & & \\
\hline 4 & $0.580 * *$ & $0.627 * *$ & 1 & & \\
\hline 6 & $0.645^{* *}$ & $0.710^{* *}$ & $0.623^{* *}$ & - & 1 \\
\hline \multicolumn{6}{|c|}{ Makenene } \\
\hline 2 & 1 & & & & \\
\hline 3 & $0.906 * *$ & 1 & & & \\
\hline 4 & $0.830 * *$ & $0.912^{* *}$ & 1 & & \\
\hline 5 & $0.532 * *$ & $0.589^{* *}$ & $0.686^{* *}$ & 1 & \\
\hline 6 & $0.665^{* *}$ & $0.732 * *$ & $0.870^{* *}$ & $0.671^{* *}$ & 1 \\
\hline \multicolumn{6}{|c|}{ Ongot } \\
\hline 2 & 1 & & & & \\
\hline 3 & $0.734 * *$ & 1 & & & \\
\hline 4 & $0.661 * *$ & $0.867^{* *}$ & 1 & & \\
\hline 5 & $0.237^{*}$ & $0.431 * *$ & $0.526^{* *}$ & 1 & \\
\hline 6 & $0.498 * *$ & $0.565^{* *}$ & $0.655^{* *}$ & $0.299^{* *}$ & 1 \\
\hline
\end{tabular}

\section{Crown diameter}

\begin{tabular}{llllll}
\hline Year & $\mathbf{2}$ & $\mathbf{3}$ & $\mathbf{4}$ & $\mathbf{5}$ & $\mathbf{6}$ \\
\hline Boumyebel & 1 & & & & \\
2 & $0.795^{* *}$ & 1 & & \\
3 & $0.605^{* *}$ & $0.738^{* *}$ & 1 & \\
4 & \multicolumn{5}{c}{1488}
\end{tabular}




\begin{tabular}{|c|c|c|c|c|c|}
\hline 5 & $0.504 * *$ & $0.512 * *$ & $0.547 * *$ & 1 & \\
\hline 6 & $0.613 * *$ & $0.582 * *$ & $0.565^{* *}$ & $0.467 * *$ & 1 \\
\hline \multicolumn{6}{|c|}{ Kekem } \\
\hline 2 & 1 & & & & \\
\hline 3 & $0.699 * *$ & 1 & & & \\
\hline 4 & $0.421 * *$ & $0.662 * *$ & 1 & & \\
\hline 5 & $0.256^{* *}$ & NS & $0.226 * *$ & 1 & \\
\hline 6 & $0.544 * *$ & $0.649 * *$ & $0.547 * *$ & $0.217 *$ & 1 \\
\hline \multicolumn{6}{|c|}{ Makenene } \\
\hline 2 & 1 & & & & \\
\hline 3 & $0.709 * *$ & 1 & & & \\
\hline 4 & $0.542 * *$ & $0.768 * *$ & 1 & & \\
\hline 5 & $0.405^{* *}$ & $0.551 * *$ & $0.614 * *$ & 1 & \\
\hline 6 & $0.558 * *$ & $0.688 * *$ & $0.814 * *$ & $0.644 * *$ & 1 \\
\hline \multicolumn{6}{|c|}{ Ongot } \\
\hline 2 & 1 & & & & \\
\hline 3 & $0.757 * *$ & 1 & & & \\
\hline 4 & $0.595 * *$ & $0.765 * *$ & 1 & & \\
\hline 5 & $0.239 *$ & $0.316^{* * *}$ & $0.448 * *$ & 1 & \\
\hline 6 & $0.599 * *$ & $0.631 * *$ & $0.684 * *$ & $0.391 * *$ & 1 \\
\hline
\end{tabular}

\section{DISCUSSION}

This study investigated methodological approaches for the selection of genotypes from experimental trials of safou in Cameroon for a domestication program. Family variation was insignificant for most fruit traits in two of the four provenances, indicating that family selection in the sixth year would not be very useful for all provenances in this domestication program. The few studies that have been undertaken in safou suggest the presence of continuous tree to tree genetic variation in fruit traits from natural populations (Leakey and Ladipo, 1996; Leakey et al., 2002; Waruhiu et al., 2004; Anegbeh et al., 2005). Phenotypic selection of all families with a few individuals in each family can provide both genetic diversity and gain for the sustainability of the domestication program. This method has been recommended in most tree improvement programs, especially when early turn over and low cost is required.
The positive correlations between growth traits, between fruit traits, and in some cases between growth traits and yield, suggest that selection for one trait could lead to indirect positive responses in the other traits that are positively correlated with the trait under selection. The positive correlations in this trial could have resulted from common environmental effects, pleiotropy (i.e., the traits have common genes) and/or genetic linkage between genes that affects both traits giving linkage disequilibrium (White et al., 2007). Research on correlations between fruit traits of younger and older trees and heritability of fruit traits are needed in order to assess the potential for early selection based on fruit traits.

This is the first time that correlations have been reported in this species, so comparisons can only be made with other perennial species. For example, Sena et al. (1994) reported a positive correlation between nut weight and yield of Anacardium occidntiale L; and Atangana et al. (2002) 
found strong positive relationships among fruit weight and dimensions of Irvingia gabonensis in Cameroon and Nigeria. In contrast, Leakey et al. (2004) reported weak negative correlations among kernel, fruit and nut length of I. gabonensis from Cameroon and Nigeria. In addition, Abasse et al. (2011) found that correlation between fruit and kernel weights differed among natural populations of Balanites aegyptiaca (L.) Delile. in Niger: i.e. it was positive, negative or not significant depending on the population.

Positive correlations between growth traits at different ages suggest that early selection based on growth could be effective in this species, assuming of course that the growth traits are moderately heritable (Sotelo Montes et al., 2006; Weber et al., 2011). As others have reported (Lambeth, 1980; Riemenschneider, 1988; Matheson et al., 1994), correlations were generally stronger between two consecutive years (e.g. year 2 and 3) and weakest between the first and the last measurement year.

\section{ACKNOWLEDGEMENTS}

We acknowledge the assistance of the farmers of Ongot, Boumyebel, Kekem and Makenene for having collaborated in the collection of germplasm for setting up of this trial. Special thanks are extended to the technicians of ICRAF notably Chin Louis and Mbouombou Amadou for their active participation in the selection of plus-trees, collection of seeds, raising of seedlings, establishment of the field trial and in the collection of data. We are grateful for the financial support of International Fund for Agricultural Development (IFAD) and European Union (EU).

\section{REFERENCES}

Abasse T, Weber JC, Katkore B, Boureima M, Larwanou M, Kalinganire A. 2011. Morphological variation in Balanites aegyptiaca fruits and seeds within and among parkland agroforests in Eastern Niger. Agroforestry Systems, 81: 57-66.

Anegbeh PO, Ukafor V, Usoro G, Tchoundjeu Z, Leakey RRB, Schreckenberg K. 2005. Phenotypic variation of fruit traits from
100 trees in Southeast Nigeria. New Forests, 29: 149-160.

Atangana AR, Ukafor V, Anegbeh P, Asaah E, Tchoundjeu Z, Fondoun JM, Ndoumbe M, Leakey RRB. 2002. Domestication of Irvingia gabonensis: 2 . The selection of multiple traits for potential cultivars from Cameroon and Nigeria. Agroforestry Systems, 55: 221-229.

Awono A, Ndoye O, Schreckenberg K, Tabuna H, Isseri F, Temple L. 2002. Production and marketing of Safou (Dacryodes edulis) in Cameroon and internationally: market development issues. Forest, Trees, and Livelihoods, 12(1/2): 125-147.

Cornelius J, Clement CR, Weber JC, Sotelo Montes C, van Leeuwen J, Ugarte-Guerra LJ, Arévalo-López L. 2006. The trade-off between genetic gain and conservation in a participatory improvement programme: the case of peach palm (Bactris gasipaes Kunth). Forests, Trees and Livelihoods, 16: $17-34$

Falconer DS, Mackay TFC. 1996. Introduction to Quantitative Genetics. Addison Wesley Longman Limited: Edinburgh.

Franzel S, Jaenicke H, Janssen W. 1996. Choosing the right trees: setting priorities for multipurpose tree improvement. Research Report 8. ISNAR, The Hague: The Netherlands, p. 87.

Isseri FG. 1998. Etude phytogeographique du safoutier (Dacryodes edulis) et quantification de la production de safou au Cameroun. Mémoire de Maitrise, Université de Ngaoundere, Cameroon, p. 65.

Lambeth CC. 1980. Juvenile-mature correlations in Pinaceae and implications for early selection. Forest Science, 26: 571-580.

Leakey RRB, Ladipo D. 1996. Trading on genetics variation in fruits of Dacryodes edulis. Agroforestry Today, 8: 16-17.

Leakey RRB, Atangana AR, Kengni E, Waruhiu AN, Usoro C, Anegbeh PO, Tchoundjeu Z. 2002. Domestication of Dacryodes edulis in West and Cebtral Africa: Characterisation of genetic 
variation. Forest, Trees and Livelihoods, 12: $57-71$.

Leakey RRB, Tchoundjeu Z, Smith R, Munro $\mathrm{R}$, Fondoun JM, Kengue J, Anegbeh P, Atangana A, Waruhiu A, Asaah E, Usoro C, Ukafor V. 2004. Evidence that subsistence farmers domesticate indigenous fruits (Dacryodes edulis and Irvingia gabonensis) in Cameroon and Nigeria. Agroforestry Systems, 60: 10111.

Matheson AC, Spencer DJ, Magnussen D. 1994. Optimum age for selection in Pinus radiate using basal area under bark for age-age correlations. Silvae Genetica, 43: 352-357.

Mbofung CMF, Silou T, Mouragadja I. 2002. Chemical characterization of Safou (Dacryodes edulis) and evaluation of its potential as an ingredient in nutritious biscuits. Forest, Trees and Livelihoods, 12: 105-118.

Riemenschneider DE. 1988. Heritability, ageage correlations and inferences regarding juvenile selection in jack pine. Forest Science, 34: 1076-1082.

Schreckenberg K, Degrande A, Mbosso C, Boli Baboule Z, Boyd C, Enyong L, Kanmegne J, Ngong C. 2002a. The social and economic importance of Dacryodes edulis (G.Don) H.J. Lam. in southern Cameroon. Forest, Trees and Livelihoods, 12: $15-40$.

Sena DK, Lenka PC, Jagadev PN, Sashikala B. 1994. Genetic variability and character association in Cashew (Anacardium occidntiale L.). Indian Journal of Genetics and Plant Breeding, 54: 304309.

Shelbourne CJA. 1992. Genetic gains from different kinds of breeding population and seed or plant production population. South Africa Forestry Journal, 160: 49-65.

Sotelo Montes C, Hernández R, Beaulieu J, Weber JC. 2006. Genetic variation and correlations between growth and wood density of Calycophyllum spruceanum Benth. at an early age in the Peruvian Amazon. Silvae Genetica, 55: 217-228.

Sotelo Montes C, Garcia RA, Agostinho da Silva D, Ines Bolzon de Muniz G, Weber JC. 2010. Variation and correlations in traits of Prosopis africana and Balanites aegytica in the West Africa Sahel: implications for tree domestication programs. Forest, Trees and Livelihoods, 19: 289-298.

Tchoundjeu Z, Kengni J, Leakey RRB. 2002. Domestication of Dacryodes edulis; State of - the - art. Forests, Trees and Livelihoods, 12: 3-13.

Tchoundjeu Z, Asaah E, Anegbeh P, Degrande A, Mbile P, Facheux C, Tsobeng A, Atangana AR, Ngo-Mpeck ML, Simons AJ. 2006. Putting participatory domestication into practice in West and Central Africa. Forests, Trees and Livelihoods, 16: 53-69.

Waruhiu AN, Kengue J, Atangana AR, Tchoundjeu Z, Leakey RBR. 2004. Domestication of Dacryodes edulis. 2. Phenotypic variation of fruit traits in 200 trees from four populations in the humid lowlands of Cameroon. Food, Agriculture and Environment, 2: 340-346.

Weber JC, Sotelo Montes C, Ugarte J, Simons AJ. 2009. Phenotypic selection of Calycophyllum spruceanum on farms in the Peruvian Amazon: evaluating a lowintensity selection strategy. Silvae Genetica, 58: 172-179.

Weber JC, Sotelo Montes C, Cornelius J, Ugarte J. 2011. Genetic variation in tree growth, stem form and mortality of Guazuma crinita in slower- and fastergrowing plantations in the Peruvian Amazon. Silvae Genetica, 60: 70-78.

White TL, Adams WT, Neale DH. 2007. Forest Genetics. CABI Publishing: USA. 